\title{
The future journalists of Timor-Leste Job expectations, knowledge and skills in multimedia journalism
}

\begin{abstract}
In April 2019, Jakarta-based UNESCO with two lecturers from the Department of Communication Science at Universitas Gadjah Mada (UGM) and one researcher at PR2Media prepared a plan to hold multimedia journalism training workshops at the Department of Social Communication (DSC) of the Universidade Nacional Timor Lorosa'e (UNTL) in Timor-Leste (East Timor). This article describes the current aspirations of the trainees related to their future media and journalism career in East Timor as well as the reflective evaluations of the Indonesian trainers on the training complemented with students' pre-test and post-test survey on multimedia journalism knowledge and skills. Participants on the multimedia journalism training carried out in July-August 2019 were adept with the required technological skills. Their biggest challenges came from basic language and journalism skills, such writing in good Tetum, Portuguese, Indonesian or English (in East Timor, Tetum and Portuguese are the official languages, while Indonesian and English were designated as 'working' languages), covering the stories, and presenting the stories in a journalistic style. Despite these challenges, they were finally able to produce basic multimedia stories with a local perspective on the designated news site.
\end{abstract}

Keyword: East Timor, journalism education, multimedia journalism, TimorLeste, UNTL

\section{GILANG DESTI PARAHITA \\ ZAINUDDIN MUDA Z. MONGGILO \\ Universitas Gadjah Mada, Yogyakarta \\ ENGELBERTUS WENDRATAMA \\ PR2Media, Indonesia}

\section{Journalism education in the global and Asia Pacific contexts}

N 2015, Hanusch et al. (2015, p. 143) stated that 'studying journalism students allows us to examine future journalists at a very early stage of their career, providing an insight into the way in which their views are shaped through the university experience'. The prominent reflection is on how journalism education 
can improve the employability of graduates in the workplace (Weaver, Beam, Brownlee, Voakes, \& Wilhoit, 2007). Unfortunately, it is not often experienced by journalism school graduates in Asian countries with mostly limited media freedom (International Freedom of Expression Exchange, 2006).

Working in countries with a media freedom status that is still partly free or not free is another obstacle in achieving professionalism for journalists in Asia (Southeast Asian journalists, for example) (Arao \& Löffelholz, 2011; Chongkittavorn, 2002, 2011a, 2011b; Konrad-Adenauer-Stiftung, 2014; Parahita \& Nyarwi, 2019). In an Asian context, journalists share a cultural identity and work collegially through associations to fulfill the human rights for freedom of information at various levels of life (Opiniano et al., 2018).

Like Western countries, journalism educators in Eastern countries are also based at various universities teaching communication, media, and journalism for undergraduate and graduate degrees (master's and doctoral programmes). They also have followed Western learning models, especially from the United States (Sarkar, et al., 1990; Hwa \& Ramanathan, 2000). What makes a difference between the two educational contexts is that at the postgraduate level, journalists are equipped with additional knowledge and skills that are more focused and specific to accommodate challenges in the workplace (Folkerts, 2014; Opiniano, 2017; Schultz, 2002). Thus, educators are expected to be capable of presenting contextual learning material for each level to enable their students to achieve graduate competency targets in line with expectations.

In this case, it is also important to underline that journalism instructors with specific educational backgrounds and different interests are allowed to provide varied perspectives in learning, but it would be ideal if it does not leave the essence of journalism on the practical or theoretical side. By so doing, the proportional creations and innovations in learning journalism at the higher education level can be achieved. Journalism educators take part in preparing learning curricula that can enhance the mastery of journalism skills of learners, enabling them to participate in achieving democracy (UNESCO, 2007).

Related to learning materials, journalism educators need to arrange and ensure that the curriculum taught has coherence, for instance, with the aims of the media industry. This is considered important because some Western countries - as the central model for journalism education in Eastern countries - are still facing challenges regarding how to design a comprehensive journalism education curriculum with the emphasis on journalistic basic skills such as interviewing, reporting, writing, and editing. However, it also creates a strong attachment and sustainability between what has been learned at the undergraduate level and what will be applied in the workplace or studied in greater depth at postgraduate level (Adam, 2001; Morgan. 2000).

It is undeniable that the relations of the workplace and the academe which 
are increasingly emerging in the era of convergence contribute to create more intensive joint learning spaces to discuss a number of current journalism issues (Dweyer, 2010; Kolodzy, Grant, DeMars, \& Wilkinson, 2014). Nevertheless, it is also important to know that graduates of communication, media and journalism schools will not always work as journalists for certain media. Other related professional options are also available such as being a researcher, trainer, lecturer, or content creator.

Regarding the encouragement of journalism education, it is necessary to revisit the set of practical skills and competences acquired from journalism education in the higher education institutions (Donsbach, 2014). According to Donsbach (2014), journalism education should involve teaching students a new set of specific competencies which are general competence, process competence, journalistic skills, and professional values.

Deuze (2004) has argued that new media technologies require journalists to master newsgathering and storytelling techniques in all media formats and reconfigure the news producer-consumer relationship. Multimedia journalism skills range from a comprehensive overview of what news is, what good reporting is, where news is found, how a text-based news report should be written and structured, and how multimedia reporting with the effective use of text, still images, audio, and video should be integrated (Bull, 2010).

\section{Contemporary issues of the East Timor press}

Language, limited internet speed and other technological facilities, financing, and quality have become current challenges of the East Timor press. Education and language of delivery are the central issues after most of East Timor's teachers, who were transmigrants, returned to Indonesia (Smith, 2002). Currently there is no one language that all East Timorese speak. Officially, Portuguese has become the official language of the country and Tetum has been taught in schools, while English and Indonesian are working languages since 2000 (Taylor-Leech, 2005). As Tetum lacks formal functions and genre, abstract language and technical terms, journalists often borrow words from Portuguese although this causes ambiguity and confusion (Taylor-Leech, 2005). The language confusion is reflected in the newspaper Suara Timor Lorosae (The Voice of East Timor) featuring stories in Indonesian, Portuguese, English, and Tetum.

The press in East Timor was rebuilding steadily although the rest of the world has been unable to access local news stories due to the fact that none of the Dili-based news media appeared online (Cokely, et al., 2000). Although this has changed with the advent of the multilingual Tatoli (Timor-Leste News Agency) website in $2019 \mathrm{http}: / / w w w . t a t o l i . t l /$. After the end of Indonesian rule, telecommunications were handled by Telstra and the districts were reliant on a full user pays cellular service (Smith, 2002). 
To rebuild the country's press, in its early years after the Referendum, East Timor received a hand from the East Timor Press Project organised by the University of Queensland, Center for International Journalism (CIJ) and Reuters Foundation. Twelve East Timorese journalists from the new newspaper Timor Post, developed by former journalists of Suara Timor Lorosae, Lalenok and Tatalikum news magazines attended a post-conflict journalism training programme in Brisbane, Australia, in February 2000 (Cokely, et al., 2000). The Timor Post, headed by former managing editor of Suara Timor Leste Aderito Hugo da Costa (Steele, 2007), published its first edition in Tetum using computers and printing equipment provided by Queensland Newspapers.

Xanana Gusmao invited Suara Timor Lorosae, a newspaper developed during the invasion of Indonesia, to resume publication in July 2000 (Steele, 2007). The Independente emerged in 2011 and become the island nation's fourth daily newspaper (Perrottet \& Robie, 2011). The newspapers which circulate with less than 1000 copies each survived because of the government subsidies (Steele, 2007). Many Timorese public officials today express disappointment with the quality and performance of the press (Steele, 2007). On the other hand, East Timorese journalists face a lack of understanding and realisation of press freedom among government officials. Although members of the Timorese government generally support the idea of freedom of the press, they are divided in opinion over the issue of criminal defamation (Steele, 2007).

David Robie (2013), who joined a team organised by the New Zealand Electoral Commission in 2007 to monitor progress with the evolving media since the first election in 2002 noted that, while commending the Timorese media for their efforts in covering the first elections, an overall information strategy for TimorLeste was absent and he predicted that the nation would risk 'being information poor' for years to come. The mission witnessed that leading politicians lacked a 'whole-hearted commitment' for a free and independent media (Robie, 2013).

\section{Method}

At UGM, communication students with a specialisation in journalism are equipped with practical multimedia skills such as photography and videography as well as working with an online news environment. Our training materials for UNTL students was adapted from the online journalism course of UGM. Thus, our goals in the training were to enable the students to understand the basic concepts of photo-journalism and video-journalism and enable them to produce one-minute journalism videos and a photo-story for Notisia Lorosae (http://notisialorosae.net).

To understand the expectations and skills of the communication students with a journalism major at UNTL and evaluate the training, we conducted pre-test and post-test surveys with the trainees. The trainees of the short course 
were selected from the fourth year (2016) and third year (2017) intakes of communication students with 50 percent from each cohort. Interviews with some trainees were intended to comprehend the goals, opinions, and existing skills in multimedia journalism.

Of 70 trainees, only 63 questionnaires were completed. The pre-test questionnaires were distributed to the students on the first day of the training before the materials were given (Table 1). Sixty five percent of the trainees were female. The post-test questionnaires were filled on the 14th day of the training. The training materials comprised the elements of journalism reports, the ethics to conduct interviews and the way to edit photos and videos with easily downloaded software for smartphones or free download ones for desktop computers. The students were divided into three classes and the trainers moved between each of the classes after two or three days.

The name of the web platform, 'notisia lorosae', was chosen after consultation with some locals who had studied on a master's degree programme at the Department of Communication Science at UGM. The website contains several categories such as business, community, environment, sports, education, politics, art and culture, and society.

On the first two days of the training, trainees were given short explanations on current professional standards relating to online media and digital platforms, journalism ethics, and knowledge on journalistic skills. On the third day, the trainees conducted field reporting and produced news photos. They visited popular public spaces in Dili such as Colmera Tais Market, Taibesi Market, Coconut Beach, and Cristo Rey. On the fourth day, they collaboratively worked in groups or individually to create photo stories and uploaded them on Notisia Lorosae (http://notisialorosae.net). On the fifth day, trainers moved to the next scheduled class and taught video journalism. The main focus in the video journalism training was to present how to create a simple video story about the lives of locals and tourist destinations in Dili and surrounding areas. They conducted the field reporting on the sixth and seventh days.

Video editing was conducted on the eighth and ninth day using personal laptops and smartphones. Software used included Movavi, VivaVideo, Adobe Premiere and Kinemaster. Many of the students brought laptops with Windows processors under Core i3, for example AMD, Atom and Intel Inside. On day 11, each class held an evaluation and completed the questionnaires. Language became a communication barrier between the trainers and trainees. Only some students understood the Indonesian language in each class but the class managed to produce photos and videos in Indonesian and Tetum.

The pre-test and post-test were answered using Likert model in which score 1 represented very positive and score 5 represented very negative. The Parametric T-test Paired Analysis was used in the survey analysis because the questions' 


\section{Table 1:Timor-Leste journalism skills, 2019}

\begin{tabular}{|c|c|c|}
\hline No. & Aspect & Questions \\
\hline \multirow{9}{*}{1} & \multirow{9}{*}{$\begin{array}{l}\text { Goals in attending multimedia } \\
\text { journalism course }\end{array}$} & $\begin{array}{l}\text { Which profession in communication are you } \\
\text { interested in? }\end{array}$ \\
\hline & & 1. Print media journalist \\
\hline & & 2. Online media journalist \\
\hline & & 3. Online citizen journalist \\
\hline & & 4. Online content creator \\
\hline & & 5. Public relations officer \\
\hline & & 6. Social media administrator \\
\hline & & 7. Campaign consultant \\
\hline & & 8. Columnist \\
\hline \multirow{9}{*}{2} & \multirow{9}{*}{$\begin{array}{l}\text { Opinions on multimedia } \\
\text { journalism }\end{array}$} & $\begin{array}{l}\text { In your opinion, which journalistic skills need } \\
\text { to be mastered? }\end{array}$ \\
\hline & & 1. To differentiate facts and opinions \\
\hline & & 2. To sonduct interviews \\
\hline & & 3. To produce written journalistic reports \\
\hline & & 4. To edit text reports \\
\hline & & 5. To produce photo journalism \\
\hline & & 6. To combine photos into slideshows \\
\hline & & 7. To cover events for video news \\
\hline & & 8. To edit video news \\
\hline \multirow{9}{*}{3} & \multirow{9}{*}{ Skills on journalism } & $\begin{array}{l}\text { Currently, which journalistic skills are already } \\
\text { mastered? }\end{array}$ \\
\hline & & 1. To differentiate facts and opinions \\
\hline & & 2. To conduct interviews \\
\hline & & 3. To produce written journalistic reports \\
\hline & & 4. To edit text-based reports \\
\hline & & 5. To produce photo journalism \\
\hline & & 6. To combine photos into slideshows \\
\hline & & 7. To cover events for video news \\
\hline & & 8. To edit video news \\
\hline
\end{tabular}

Note: The questionnaires were conducted on the 17th day of the training course in Dili, Timor-Leste, July 2019.

sets were the same in both tests and we intended to see the change. Interviews with students were conducted to probe further about their career aspirations. Additionally, to comprehend the current practice of journalism education in UNTL and job opportunities in East Timor, we interviewed the commissioner of the Press Council Jose Ximenes and the Head of the Department of Social 
Communication Marcellino. The triangulation analysis was applied for all interviews and statistical analysis. Our perception as the trainers complemented the triangulation analysis of the study.

\section{Results and discussion}

When arriving in Nicolo Lobatou Airport on sunny bright day at the end of July 2019 , we were told by the locals that the country was in economic crisis. Kingsbury (2017) analysed that the economic problems of East Timor were related to a high dependency on petroleum. On the way to UNTL on the first day, we bought and read an edition of Suara Timor Lorosae (previously Suara Timor Timur) with 16 pages of eight columns priced at 50 centavos (or US\$0.5). The Opiniaun, Internasional, Naran and Atividade (people and activity) sections were in Indonesian while the rest were in Tetum and Portuguese. The fact that the paper had its online version on Suara Timor (http://suara-timor-lorosae. com) assured us that teaching multimedia journalism was relevant to the future career needs of communication students in UNTL.

Communication students at UNTL were engaged with social media. On average, the trainees spent US\$5 a month for internet usage. This means that while US\$5 only allowed them to buy Suara Timor Lorosae ten times, with the same amount of money they were able to access WhatsApp, YouTube, Instagram, Facebook, and Twitter. However, the internet connection with US\$5 might not last a month. Often they went online for a limited period as the data quota allowed. During the training, the trainers bought extra internet data packages and shared them in the classes as many students did not have internet data.

Once they were able to connect to the internet, they watched YouTube personalities such as Maria Vittoria, Feliz Official and Ary Bargon. When the trainers presented the career possibilities a journalism graduate can have, the trainees were enthusiastically responding with questions like how they could gain money from YouTube, how they could set up a PayPal account, what kind of content they should focus on to create and who would watch their content.

However, when students were asked for the names of news media they consume, they mostly read print media. They placed The Timor Post and Jornal Independente at the top of the list, followed by Suara Timor Lorosae and Jornal Nacional Dia 'rio. Radio Liberdade was the most familiar radio station among the trainees but some of them also listened to Radio Televisiau Timor Leste (RTTL), Radiu Groupo Media Nacional (GMN) and Radiu Akademika. GMN TV and TV Telemor were the most watched local television channels besides Gardamor and RTTL. Some of the students watched programmes on RCTI and SCTV; both are Indonesian television channels. Tempo Timor, Tatoli, Tafara and Sapo Timor Leste were the local online press read by the students.

If the percentages of both broadcast stations were combined, 60 percent of 


\begin{tabular}{|l|c|c|c|}
\hline \multicolumn{2}{|l|}{ Table 2: Media type preferred by Timor Leste trainees, 2019 } \\
\hline Media type & Frequency & Percent & $\begin{array}{c}\text { Cumulative } \\
\text { percent }\end{array}$ \\
\hline Terrestial TV & 21 & 33.3 & 33.3 \\
\hline Terrestial Radio & 17 & 27.0 & 60.3 \\
\hline News Agency & 8 & 12.7 & 73.0 \\
\hline Newspapers & 6 & 9.5 & 82.5 \\
\hline Magazines & 2 & 3.2 & 85.7 \\
\hline Internet-based Media & 4 & 6.3 & 92.1 \\
\hline Not knowing yet & 3 & 4.8 & 96.8 \\
\hline Others & 1 & 1.6 & 98.4 \\
\hline Do not want to be a journalist & 1 & 1.6 & 100 \\
\hline Total & 63 & 100.0 & 100.0 \\
\hline
\end{tabular}

the students aspired to work as television and radio journalists (Table 2). Only some of them were interested in working for news agencies, print media and internet-based media. Almost all of the students intended to work as journalists.

The declining media company business did not discourage journalism students at UNTL from pursuing a media career after graduation. From the statements of the students we interviewed, they all wanted to be media workers, ranging from radio broadcasters, cameramen, television presenters, television reporters, filmmakers, to media officers in government offices.

One of the students, Iriana Soares, before starting college, wanted to be a radio announcer. However, after three years at college and trying out audio visual equipment, she now wants to be a television presenter or an independent filmmaker. According to her, the most important thing she had learned so far was the ability to make videos and edit them. 'It's very fun and challenging. I want to be an independent filmmaker because I can be free to create any stories, as I wish,' said Soares.

The Department of Social Communication at UNTL has a number of professional cameras provided by the Australia government, well-kept in the storage room of the laboratory, and two working desktop computers with Adobe Premiere and Audition software. Technical challenges faced during the training were the slow internet connectivity and limited numbers of students possessing laptops. We bought Telemor for US\$10 per class during the two-week training for uploading the trainees' works but the connection speed was limited. Given the situation, we spent a day in the UNESCO office in the United Nations Compound to upload the videos of the students. We further published the testimonies of the trainees on Notisia Lorosae YouTube channel.

The technical difficulty resembled the East Timor Press Project led by QUT's 


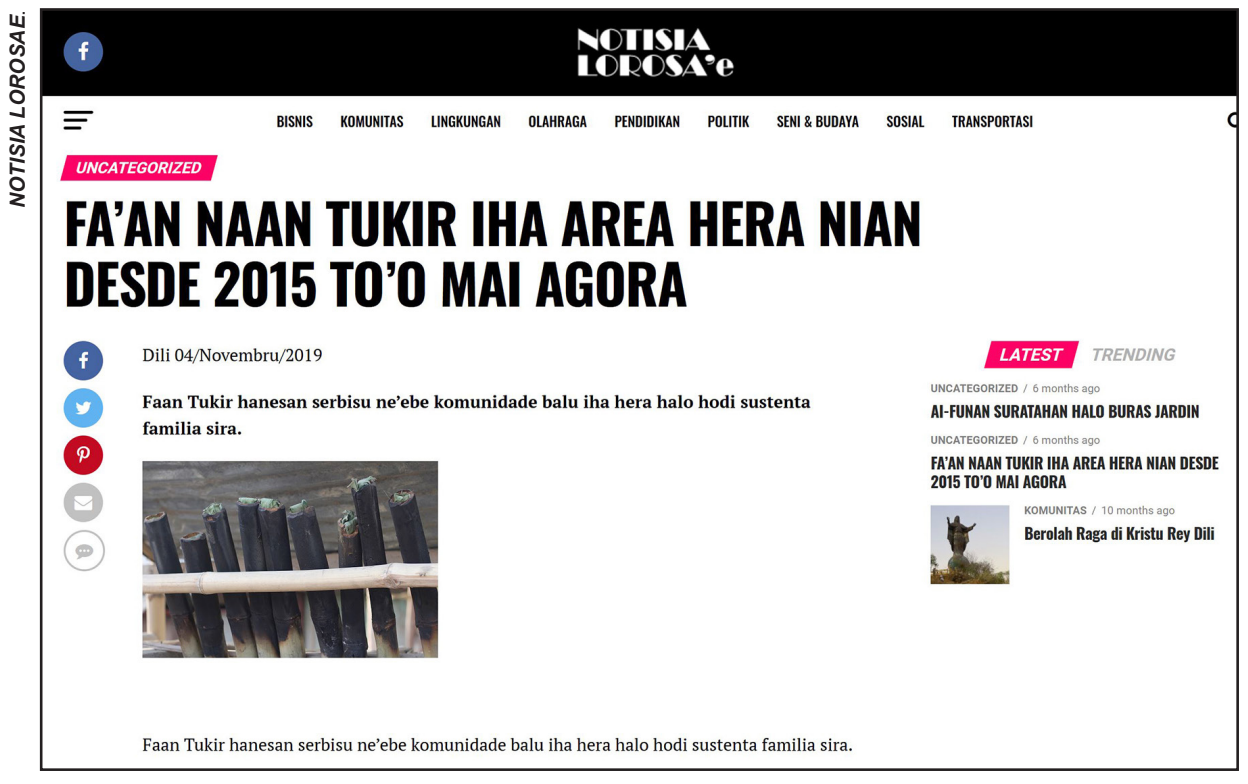

Figure 1. A photo-story in Tetum created by a student at UNTL uploaded on Notisia Lorosae.

journalism programme in 2000. Cokely, et al. (2000, p. 32) reported that 'the poor state of communication infrastructure and the widespread devastation of East Timorese society means that the impact of the Project as a wealth-generation strategy and as an exercise in democratic nation-building will initially be extremely limited.' We did not ask through questionnaires about the students' perceptions of the website and the use of website to publish their work but during the class, students showed enthusiasm in learning how to upload photos and videos and felt proud of their work being published.

Based on the responses on the pre-test and post-test questions, not much change was found in the trainees' perceptions on their future goals, opinions on required skills in multimedia journalism, and existing skills. In both surveys, trainees mostly agreed that multimedia journalists should be able to differentiate fact and opinions, conduct interviews, produce written journalism reports, edit text reports, produce photo journalism, combine photos into slideshows, cover events for audiovisual news, and edit audiovisual news. They also perceived that their current skills were sufficient, high or very high.

According to the data, not much change was found in the trainees' perceptions on their future goals, opinions on required skills in multimedia journalism, and existing skills. The students felt that they know what they want to do after they graduate, and they have the relatively high knowledge and skills on multimedia journalism. In other words, the trainees have had pre-existing expectations regarding their future jobs and these are typically found among 
journalism students who are living under digitally saturated environments like their counterparts in Indonesia.

The lack of attitude change in the surveys might be due to the answers of the students being in ordinal/Likert, not in intervals. Thus, the responses tended to be subjective. In addition, the questions did not cover the area of online literacy, especially in uploading content on website and ability in expressing news in written text. The language barrier (questionnaires written in Indonesian) and the tendencies to answer with positive conformity could be other factors. The short duration of the training might contribute to the low significance.

The high ability of the students to take and edit photos and videos has been consistent with our subjective assessment. In our opinion, trainees were able to produce quality photo and video. However, students found it difficult to conduct interviews and create the stories based on the interviews for the pictures' captions and videos subtitles. For example, on the video of the limited number of Taibesi Market, students needed to be guided in mentioning the name and the age of the news sources more accurately, and in explaining the stages of the story. The next training should stress the basic journalism skills such as how to develop news ideas into news stories, prepare questions and develop them during the interviews to conduct interviews and verification, and differentiate facts from opinions.

Writing the captions and subtitles was the slowest part of the process. As the trainers were Indonesian, students strove to speak and write in Indonesian. They were allowed to write in Tetum and a lecturer at UNTL would orally translate them for the Indonesian trainers. However, most of the students wrote their subtitles and captions in Indonesian. Only some of them wrote in Tetum (Figure 1).

Despite the language and cultural challenge, the trainees came up with unique and publicly relevant news angle ideas. The first thing we explained in the class was the importance of news in society, for example, the ability of news media to criticise public services and facilities, and the way simple daily life stories might interest the audiences. The angles of their journalism reports were varied from places-bound focus to activities and people. As they became more critical, one group covered littering problems at Taibesi Market in Dili and a famous tourism spot, Cristo Rey.

At UNTL, journalism education is part of the Department of Social Communication, which was established in 2008 as a part of the Faculty of Social Sciences. It is one of only two communication schools in East Timor-the other is the Department of Social Communication at Universidade Oriental de Timor Lorosa'e (UNITAL), a private university located in Dili. With ten lecturers, there are always 80-100 students enrolled at the UNTL's Department of Social Communication every year. 'But for the class of 2019, we were forced to accept 300 students because there was a policy from the university to accommodate the children of veterans of the war of independence,' said Marcelino Magno, chair 
of the Department of Social Communication at UNTL. The tuition fee is as low as US\$5 per semester.

According to Magno, the imbalance in the number of lecturers and students is one of the main challenges of education here. With a total of 10 lecturers, added with six guest lecturers, the Department of Social Communication is struggling even to fulfill its schedule. In addition, not all lecturers have a communication education background. In fact, Magno is the only one with a background in journalism in which he graduated from the Universitas Gadjah Mada's Department of Communication in Indonesia and had worked as a reporter for Tempo magazine in Indonesia for one year.

Regarding teaching in the Department of Social Communication in general, Magno said, during the first three semesters, the students specifically study the theory. 'In the first semester, they study general subjects such as Mathematics, Portuguese, English, Introduction to Political Science, and Introduction to Social Sciences. In the second and third semester, they only learn communication theories, including journalism,' he said.

During semesters 4 and 5, they specifically take practical courses, both to make journalistic and non-journalistic products, using a variety of multimedia tools. 'We strongly emphasise the importance of technical skills, so that after graduation they are ready to work for the industry. But their storytelling ability is still weak. So, we are very pleased to have this multimedia training supported by UNESCO. This will strengthen their multimedia journalism capabilities,' Magno said.

Multimedia technology facilities at UNTL are quite complete. The basic shortcoming is only the internet infrastructure. But it is hoped that by mid-2020, with the help of the Australian government, there will be free internet services for the entire campus.

The Department of Social Communication also has Radio Akademia, a campus radio station managed by alumni of the department. Both junior and senior students do internship programmes at the radio, which is funded by the university and advertising. This terrestrial analog radio covers the whole of Dili.

According to Magno, almost all media institutions in East Timor rely on communication graduates to work as journalists. This also includes government offices, which employ communication graduates to work as public relations and media officers.

Another major challenge faced by the department is related to the very low mastery of written language by students. 'In daily conversation, they use Tetum, but for written language, Tetum must absorb a lot of Portuguese vocabularies to meet the needs of its users,' he said. According to Magno, students still find it difficult to adopt Portuguese vocabularies in Tetum; as a result, most of their sentences are grammatically incorrect. 
Meanwhile, they also cannot write and speak Portuguese, English, and Indonesian adequately. So, in our opinion, they do not master writing in any language adequately. For spoken language, they only fully master Tetum, and a little Portuguese and Indonesian.

'When a student writes a thesis and they take references from Indonesian, I ask them to always include the original Indonesian text. Because they cannot even copy Indonesian text correctly, it is always mixed with Tetum-style writing,' Magno said.

The inadequate mastery of the written language of prospective journalists then becomes the task of the news media that employs them in the midst of the depressed media business conditions in East Timor. According to Jose Ximenes, a member of the East Timor Press Council, the political and economic crisis in 2017-2018 caused government spending to decline dramatically, including advertising spending on news media. In East Timor, news media advertisements, for both print and broadcast, mostly come from the government.

Instead of developing journalist competencies, media companies have to reduce the number of employees due to the lack of advertising revenue. For example, the largest circulation newspaper in the country, Timor Post, was forced to reduce the number of journalists in 2018 from the previous number of 20 . The circulation of the Timor Post and other newspapers also depends heavily on government offices as their daily subscribers. According to Ximenes, the proportion of advertising is received mostly by newspapers, followed by television stations, while news sites still receive little due to the lack of internet access in the country.

With such difficult conditions, broadcast media cannot also be expected to recruit journalists every year. East Timor has one public television called RTTL (Radio dan Televisi Timor Leste) and two private televisions, GMN and Education TV. GMN is the largest media group in the country, whose business includes television, radio, print media, and a news website.

Today, there are 216 journalists registered with the Press Council (those who have journalist IDs published by the Press Council) and they mostly work in printed media. Meanwhile, communication school graduates who want to obtain a Press Council journalist card must have an internship in a media company for a minimum of six months. For non-communication graduates, they must have an internship of at least one year.

\section{Conclusion}

This research found that Timor-Leste journalism students in general expected to work for legacy media organisations such as television and radio stations, which might be influenced by the popularity of legacy media in the country. The interviews with students showed that they aspire to be journalists in the news industry, despite the lack of journalism job opportunities, to be information 
officers at government offices, and to be entrepreneurs in multimedia production. In addition, the students showed promising ability in producing news stories as they easily adapted to cultural differences with the trainers and with new approaches in motivating learning in multimedia journalism supported by the students' interviews. The journalism training, which was conducted in less than two weeks, might have not yielded a highly significant impact on their multimedia journalism knowledge and skills.

However, during the consultation process, the real challenge came from interviewing and writing skills. As these skills are only developed if journalism students regularly practise journalism, the curricula and facilities should provide the opportunities. Meanwhile, the interviews with a lecturer at the department and a member of the East Timor Press Council showed that to be competitive in the difficult job market, there was a need for the East Timorese journalism students to highly improve their skills in written language and journalism.

The sustainability of the website to publish the students' works depends on the UNTL's Department of Social Communication. Some students have learned how to upload and publish the photo-stories and video on both the website and YouTube. However, they were due to graduate soon. Thus, the trainers shared the knowledge to some fellows at the department as well. As the department will recruit new lecturers in future, the website will be sustained if the lecturers are able to use the website and the technology incorporated into the course process. Although the news site is not as popular as legacy media in East Timor due to the expensive internet connection, the penetration level of the internet is expected to rise in the future years as planned by the East Timorese government.

\section{References}

Adam, G. S. (2001). The education of journalists. Journalism, 2(3), 315-339. https:// doi.org/10.1177/146488490100200309

Arao, D., \& Löffelholz, M. (2011). The ASEAN guide: A Journalist's handbook to regional integration in Southeast Asia. Bonn: German International Development Cooperation (GIZ) - International Institute for Journalism.

Bull, A. (2010). Multimedia journalism: A practical guide. Oxon: Routledge.

Chongkittavorn, K. (2002). Southeast Asian media struggle to be free. Retrieved from http://niemanreports.org/ articles/southeast-asian-media-struggle-to-be-free/

Chongkittavorn, K. (2011a). Media and civil society: Vital players ASEAN must embrace. The Nation. Retrieved from http://www.nationmultimedia.com/home/2011/09/19/ opinion/Media-and-civil-society-Vital-players-Asean-must-e-30165604.html

Chongkittavorn, K. (2011b). Chapter 7: Covering ASEAN for three decades. In Lee, Y. Y. (Ed.). ASEAN matters: Reflecting on the Association of Southeast Asian Nations (pp. 39-42). Singapore: World Scientific Publishing.

Cokely, J., da Costa, A. H., Lonsdale, J., Romano, A., Spurgeon, C., \& Tickle, S., (2000). Media, democracy and development: Learning from East Timor. Asia Pacific Media Educator, 9, 27-42. https://ro.uow.edu.au/cgi/viewcontent. 
cgi?article $=1136 \&$ context $=$ apme

Deuze, M. (2004). What is multimedia journalism? Journalism Studies, 5(2), 139-152. https://doi.org/10.1080/1461670042000211131

Donsbach, W. (2014). Journalism as the new knowledge profession and consequences for journalism education. Journalism, 15(6), 661-677. https://doi. org/10.1177/1464884913491347

Dweyer, T. (2010). Media convergence. New York, NY: McGrawHill.

Folkerts, J. (2014). History of journalism education. Journalism and Communication Monographs, 16(4), 227-299. https://doi.org/10.1177/1522637914541379

Hanusch, F., Mellado, C., Boshoff, P., Humanes, M.L., de Leon, S., Pereira. F., Ramirez, M.M., Roses, S., Subervi, F., Wyss, V., Yez, L. (2015). Journalism students' motivations and expectations of their work in comparative perspective. Journalism \& Mass Communication Educator, 70(2), 141-160. https://doi.org/10.1177/1077695814554295

Hwa, A. P., \& Ramanathan, S. (Eds.) (2000). Communication education in ASEAN. Singapore: Asian Media Information and Communication Centre.

International Freedom of Expression Exchange. (2006). Majority of Indonesian journalists vastly underpaid: Aliansi Jurnalis Independen [AJI] survey. IFEX Communique 15(35). Retrieved from http://www.ifex.org/en/content/view/full/76840/

Kingsbury, D. (2017, April 28). Timor-Leste's worrying economic future. East Asia Forum. Retrieved from https://www.eastasiaforum.org/2017/04/28/timor-lestesworrying-economic-future/

Kolodzy, J., Grant, A. E., DeMars, T. R., Wilkinson, J. S. (2014). The convergence years. Journalism \& Mass Communication Educator, 69(2), 197-205. https://doi. org/10.1177/1077695814531718

Konrad-Adenauer-Stiftung. (2014, September 9). Asia Pacific media update. Retrieved from https:/www.kas.de/en/web/medien-asien/single-title/-/content/asia-pacificmedia-update

Morgan, F. (2000). Recipes for success: Curriculum for professional media education. Asia Pacific Media Educator, 8, 4-21. https://ro.uow.edu.au/apme/vol1/iss8/2/

Opiniano, J. M. (2017). A two-nation Asian phenomenological study: Roles and purposes of graduate journalism education through the lens of global journalism. Pacific Journalism Review: Te Koakoa, 23(2), 26-50. https://doi.org/10.24135/pjr.v23i2.27

Opiniano, J. M., Bagtas, A. L., Basco, K. C., Her-Nandez, R. J., Lopez, E. C., Rodolfo, M. C., \& Vicho, A. K. (2018). Journalism, journalism education and region's integration: The case of Southeast Asia. Pacific Journalism Review: Te Koakoa, 24(2), 189-217. https://doi.org/10.24135/pjr.v24i2.28

Parahita, G. D., \& Nyarwi, A. (2019). What dampens the Indonesian's journalist freedom and safeness in the Post-Soeharto new order? In S. Jamil (Ed.), Handbook of research on combating threats to media freedom and journalist safety (pp. 83-105). Hershey, Pennsylvania, PA: IGI Global.

Perrottet, A., \& Robie, D. (2011). Special report: Pacific media freedom 2011: A status report. Pacific Journalism Review: Te Koakoa, 17(2), 148-186. https://doi. org/10.24135/pjr.v17i2.356

Robie, D. (2013). Conflict reporting in the South Pacific: A critical reflexive approach to Timor-Leste and West Papua. Media Asia, 40(2), 147-161. https://doi.org/10.108 0/01296612.2013.11689963

Sarkar, C., Suparto, I. R. M., bin Haji Adnan, M. H., Koirala, B. D., Maslog, C. C., \& Salayakanond, W. (1990). Communication education in Asia: Status and trends in India, Indonesia, Malaysia, Nepal, Philippines and Thailand. Manila, Philippines: 
Press Foundation of Asia.

Schultz, T. (2002). Does education matter? Characteristics of journalists who went to graduate school. Journalism: Theory, Practice and Criticism, 3(2), 223-238. https:// doi.org/10.1177/146488490200300204

Smith. A. L. (2002). Timor Leste, Timor Timur, East Timor, Timor Lorosa'e: What's in a name? Southeast Asian Affairs, 54-77.

Steele, J. (2007). The voice of East Timor: Journalism, ideology, and the struggle for independence. Asian Studies Review, 31(3), 261-282. https://doi/ org/10.1080/10357820701559071

Taylor-Leech, K. (2005). The ecology of language planning in Timor-Leste. Development Bulletin, 68, 116-120.

UNESCO. (2007). Model curricula for journalism education for developing countries \& emerging democracies. Paris, France: UNESCO.

Weaver, D., Beam, R., Brownlee, B., Voakes, P., \& Wilhoit, G. C. (2007). The American journalist in the 21st Century: U.S. newspeople at the dawn of a new millennium. Mahwah, NJ: Erlbaum.

Gilang Desti Parahita is an assistant professor in the Department of Communication Science, Faculty of Social and Political Sciences, Universitas Gadjah Mada (UGM), Jogyakarta, Indonesia. Her research topics include digital journalism, new media and marginalised communities and communication for sustainable development.

gilang_parahita@ugm.ac.id

Zainuddin Muda Z. Monggilo is a lecturer in the Department of Communication Science, Faculty of Social and Political Sciences, Universitas Gadjah Mada (UGM), Jogyakarta, Indonesia. His research topics include digital journalism and media and information literacy.

Engelbertus Wendratama is a researcher at PR2Media, a media policy and regulation think tank in Indonesia. His work has appeared in numerous print and online publications, covering multimedia journalism, disinformation, and digital governance.

Parahita and Wendratama previously developed Warga Jogja (http://www.wargajogja.net) to publish the journalistism by the UGM students at the Department since 2015. Together with Monggilo, they specifically built the page of Notisia Lorosae (http://www.notisialorosae.net) for the students of UNTL. The training was conducted from July 30 to August 9, 2019. 